\title{
Working Conditions, Co-Workers, and Leadership Styles Toward Job Satisfaction Among Local Authority Employees
}

\author{
Mohammad Faizzudin Samsuri ${ }^{1}$, Muhammad Hasmi Abu Hassan Asaari ${ }^{1}$ \& Nasina Mat Desa ${ }^{1}$ \\ ${ }^{1}$ Management Section, School of Distance Education, Universiti Sains Malaysia, Penang, Malaysia \\ Correspondence: Muhammad Hasmi Abu Hassasn Asaari, Management Section, School of Distance Education, \\ Universiti Sains Malaysia, 11800 Penang, Malaysia. Tel: 604-653-4567. E-mail: hasmi@usm.my
}

Received: November 21, 2021

doi:10.5539/ass.v18n3p12
Accepted: December 18, $2021 \quad$ Online Published: February 28, 2022

URL: https://doi.org/10.5539/ass.v18n3p12

\begin{abstract}
The local council management faced some issues on their employees concerning their job satisfaction due to working conditions, co-workers, and leadership styles. Moreover, this affects the employees' job satisfaction which in turn would also affect the local council's progress in serving the public. Thus, the objectives of the study are to unearth the relationship and understand the impact between working conditions, co-workers, and leadership styles on job satisfaction among the local council employees. Self-administered questionnaires were distributed among local council employees. Data analysis was conducted on the 121 useable questionnaires received. This study discovered that working conditions and leadership styles had an impact on the local council employees' job satisfaction. Unfortunately, co-workers had no impact on the local council employees' job satisfaction.
\end{abstract}

Keywords: working conditions, co-workers, leadership styles, job satisfaction, public servants, local authority

\section{Introduction}

Employees are important in influencing the management machinery as well as key assets that work together in achieving the goals of the establishment of the organization (Al-Zu'bi, 2010). No organization can last long without the works of its employees. As such, the organization should give some attention to their employees to maintain the consolidation of their services in the organization over a long period. Moreover, it can influence the effectiveness of productivity and innovation of an organization through the implementation of efficient and effective work by showing the determination of employees to generate excellent, glorious, and distinguished output. Meanwhile, the nation's National Labor Policy directly refers to external influences and factors that impact individuals in job satisfaction because of one of the yardsticks or policies to effectiveness. The National Labor Policy focus is the increase in labor and labors standards, and social security benefits to increase employees' motivation. This was clearly illustrated that employee satisfaction is an important construct in mobilizing an organization to achieve success as well as continuous mission and vision (Lam, 1995; Hamzah, Mahmuddin, Ayub, Ahmad, \& Nordin, 2010).

In the era of globalization and responding to the challenges of Vision 2020 in line with efforts to achieve the status of a developed country and the city, especially the local authority, of course, has relatively many areas of responsibility to be borne and provided services. Ensuring that the services offered to meet the quality standards and performance of the client's charter achievement, value, and excellence in terms of job satisfaction is highly emphasized. In general, the local authority is an institutional structure created through the legal system and their operations are limited to the jurisdiction and duties provided in the law (Jusoh \& Ahmad, 2009). Local authority objectives are to improve and preserve the quality of life of the people of Penang through quality service and development.

The local authority management faced some issues on their employees concerning their job satisfaction due to working conditions, co-workers, and leadership styles. The issues on job satisfaction should not be taken lightly by the management and employees. The lack of job satisfaction will affect employees to behave unproductively toward the local authority's progress. These behaviors would cause various additional issues on the local authority management such as profit losses, competition between local authorities, decreased productivity, and impaired effectiveness. Moreover, the local authority management faced some behavioral changes and unproductive work behaviors that often occur today are high turnover between departments and units, 
absenteeism, layoffs, unsafe behavior, provocative work climate, work stress, lack of work, property damage, and theft of government property. Some employees had done some moonlighting on their working hours for their purposes as well as triggering an increase in conflict and injustice toward their employer. The objective of the study is to unearth the relationship and the impact between working conditions, co-workers, and leadership styles toward job satisfaction among the local authority employees.

\section{Literature Review}

\subsection{Working Conditions}

Deraman and Isa (2016) stated that the workplace situation is a contribution or factor to an employee who is satisfied or dissatisfied. The environment of the workplace includes elements such as facilities and service infrastructure such as work equipment, workspace, temperature, adequate lighting, and so on. Moreover, Herzberg (1966) stated the workplace atmosphere serves as a hygiene factor that encourages employees to be satisfied or unsatisfied. This means a pleasant situation and a conducive environment will influence and increase the rate of job satisfaction. Meanwhile, Wall and Nolan (1986) concluded that the level of job satisfaction will be low if injustice occurs and cause high feelings of conflict, the majority of injustices have a high attachment to human beings rather than duties, the work situations that do not cause/provoke disputes or disputes will result in job satisfaction and thus cause the level of injustice to decrease, and the situation or work environment is closely related to some combination of factors such as physical, psychological, and environmental that impact the organization and work. Thus, the working conditions affected job satisfaction as it provided important identifications such as calm, cheerful, and harmonious working conditions have a significant relationship toward job satisfaction.

\subsection{Co-Workers}

Occhipinti, Rollo, and Klimowicz (2018) found that engagement, relationships, and support from employees influence performance and job satisfaction. They defined a co-worker as a friend of an employee in interacting, performing, or completing a job task. Subsequently, an employee can feel whether his or her co-worker is pleasant or unpleasant. In the aspect of co-workers or group of employees relationship, the interaction, communication, and sharing of views were important contributions toward job satisfaction. Group behavior, productivity levels, and work patterns were determined through the formation and involvement of workgroups. While associating with co-workers will create satisfaction for employees. On the other hand, an employee avoiding workgroups is likely to lead to behaviors such as individualistic, arrogant, and feel excluded and isolated. Katz (1964) explained that simulations, agreements, and support gained from interacting among co-workers or workgroups had an effect on motivation and increase the level of job satisfaction if they have similar behaviors and values.

\subsection{Leadership Styles}

Leadership style has been identified as a key factor in determining organizational success or failure. Leaders or leaders should have critical and constructive knowledge, think outside the box, come up with thoughtful ideas in solving an issue or problem, skilled, and capable in various aspects of interpersonal relationships such as effective communication, motivated, and have dynamic group members and sustainable. Moreover, leadership and direction in an organization were driving factors to balance and motivate the level of job satisfaction. Simon (1947) stated that the instructions given by the supervisor will be followed/complied with as long as it covers the scope or scope of work that is reasonable and acceptable to employees.

\subsection{Job Satisfaction}

In an organization, various determining factors determine the success and glory of the organization. Job satisfaction was determined through the aspects of working conditions, co-workers, and leadership style. Job satisfaction was one of the factors that determine the success of an organization. For example, employees with high job satisfaction work harder on the tasks assigned in safeguarding the interests of the organization which in turn results in success along with the efforts undertaken. Besides, job satisfaction that can be provided by the organization can maintain and attract employees with the skills performed (Rad \& Yarmohammadian, 2006). Vroom (1964) explained that a person who plays a role in the workplace based on emotions is one of the expressions of satisfaction. Job satisfaction can provide balance, support, and encouragement to employees to improve job performance as well as organizational excellence. Meanwhile, Spector (1994) stated that job satisfaction is the extent to which a person likes work (satisfaction) or does not like (dissatisfied) with the job done. The concept of job satisfaction can contribute to psychological well-being in the workplace (Robins, Tracy, Trzesniewski, Potter \& Gosling, 2001). Employees who love their work can be seen through positive emotions 
and traits/stimuli in the workplace (Shaikh, Bhutto, \& Maitlo, 2012). Satisfaction can also be exhibited as a satisfactory relationship based on the components needed by the individual as well as the segments highlighted (Locke, 1969). Furthermore, work performed in a positive or negative form can be influenced by a person's job satisfaction (Locke, 1976; Odom, Boxx, \& Dunn, 1990).

\subsection{Relationship Between Working Conditions and Job Satisfaction}

A work environment or conditions have a positive impact on employee job satisfaction. Unsatisfactory working conditions become contributors and limitations to manpower to enhance their capabilities and reach their full potential. Attribution set for working conditions is an important factor for the organization to realize the importance of a harmonious work environment while increasing job satisfaction (Raziq \& Maulabakhsh, 2015). Lee and Brand (2005) show that job satisfaction increases if the organizational environment is conducive. Overall, the studies confirmed that the level of satisfaction was good that is satisfying. On the other hand, the factors such as workplace conditions, salary, work culture, and company policy create a high level of dissatisfaction (Yusoff, Kian, \& Idris, 2013). Meanwhile, Carlopio and Gardner (1995) described the workplace environment as providing a direct relationship network to job commitment, job satisfaction, productivity, and organizational well-being. Thus, the study hypothesized that:

$\mathrm{H}_{1}$ : Working conditions have a positive relationship with job satisfaction among employees of the local authority.

\subsection{Relationship Between Co-Workers and Job Satisfaction}

Rosliza and Bakar (2018) indicated the implications of relationships established with co-workers can have a positive or negative impact on the individual based on the treatment received. Co-workers play a role in being an internal contributor that stimulates or increases the level of job satisfaction in a person. Moreover, coworker relationships created mutually influential relationships on job satisfaction (Lin \& Lin, 2011). Effective communication and social interaction that are mutually understanding and helpful can produce a large scale of job satisfaction to employees. Advisory services, guidance, and guidance are the motivators or inspiration to co-workers in solving a problem (Johari \& Hee, 2013). They also found that co-workers are a significant influence in providing job satisfaction to each individual serving in the organization.

Teamwork among co-workers should be a human resource instrument and should be used effectively to improve the overall performance of the organization (Chng, Hee, Liew, \& Loke, 2014). It also encourages public engagement to achieve goals in an integrated manner (Chng, Hee, Liew, \& Loke, 2014). The collaboration and integration process that is formed, requires coordination, goal setting, problem-solving, monitoring, and team leadership to develop efficiency and effectiveness (Chng, Hee, Liew, \& Loke, 2014). The practice of working together in an atmosphere of goodwill and creating a sense of belonging for any action will indirectly be able to meet the demands, smoothness, and interests of the organization. Moreover, team performance and achievement depend on interaction within group members (Chng, Hee, Liew \& Loke, 2014). Dependence, superior interaction, and a very harmonious relationship between employees and superiors can achieve collective objectives and intact agreements. Working as a team is more likely to create dynamic engagement and build stability as soon as job satisfaction becomes the grassroots to achieve organizational excellence. Thus, the study hypothesized that:

$\mathrm{H}_{2}$ : Co-workers have a positive relationship with job satisfaction among employees of the local authority.

\subsection{Relationship Between Leadership Styles and Job Satisfaction}

Leadership styles and supervisory concepts have an ideal relationship in job satisfaction studies. Locke (1976) stated that subordinate relations with supervisors are part of the elements that can create and realize job satisfaction. Supervisory or directive methods are characterized by unique personal qualities such as tolerance, group closeness, approachability, professionalism, engaging with subordinates for decision making, discussing in determining organizational targets while yielding productivity, effectiveness, and job satisfaction. Supervisors/leaders who behave contrary to cultural values and practices are expected to have an impact on employee dissatisfaction (Likert, 1967). McNeely (2008) found that employees who have a leader who is oriented towards employee relations and a reflection of good values will create high job satisfaction. This coincides with if a leader practices openness and the importance of a prosperous and prudent relationship, they will be respected by subordinates thus improving employee performance. Whereas, Fiedler (1967) stated the effectiveness and efficiency of a group are based on the leadership authority of a leader whose approach highlighted to its members allows it to play an important role in implementing and improving morale, ethics, group work satisfaction, and achievement in organizational progress. Thus, the study hypothesized that:

$\mathrm{H}_{3}$ : Leadership styles have a positive relationship with job satisfaction among employees of the local 
authority.

In summary, Figure 1 depicts the research framework of the study that is associated between independent variables, namely working conditions, co-workers, and leadership style toward dependent variables, job satisfaction, among employees of the local authority.

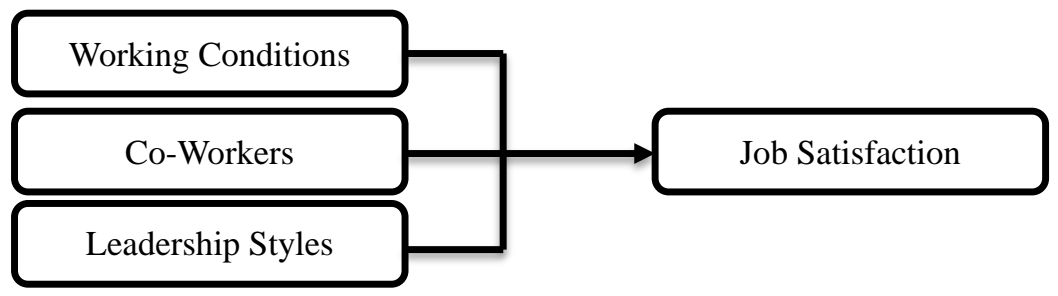

Figure 1. Research Framework

\section{Methodology}

This study employed self-administered questionnaires on the employees of the local authority in a northern state of Malaysia. The total population of the employees was 3,498. A total of 145 employees of a sub-division of the local authority has identified a sample. The employees were asked about the influence of working conditions, co-workers, and leadership style on their job satisfaction. The self-administered questionnaire 5 sections, namely Sections A: Demographic Information, Section B: Working Conditions, Section C: Co-workers, Section D: Leadership Styles, and Section E: Job Satisfaction. Firstly, the questions on working conditions were based on Kee, Low, Ooi, Sam, and Teng (2012) showed the value of the alpha coefficient was 0.77. Secondly, the questions on co-workers were based on Karatepe (2011) showed the value of the alpha coefficient was 0.82 . Thirdly, the questions on leadership styles were based on Kee, Low, Ooi, Sam, and Teng (2012) showed the value of the alpha coefficient was 0.91. Finally, the questions on job satisfaction were based on Tay, Tan, Lew, Tan \& Chea (2017) showed the value of the alpha coefficient was 0.84 .

\section{Data Analysis}

\subsection{Demographic Analysis}

Majority of the respondents were men $(n=92 ; 76 \%)$ as compared to female $(n=29 ; 24 \%)$. Respondents reported their ethnicity, Malay respondents were 107 employees (88.4\%), Chinese were 2 employees (1.7\%), Indian were 11 employees $(9.1 \%)$, and another ethnicity was 1 employee $(0.8 \%)$. Almost half of the employees were aged between 30 to 40 years old $(n=53,43.8 \%)$; and followed by 31 employees $(25.6 \%)$ were aged below 30 years old, 25 employees $(20.7 \%)$ were aged 41 to 50 years old, and 12 employees $(9.9 \%)$ were aged above 50 years old. Almost $80 \%$ of the employees were married $(n=93)$ as compared to single employees $(n=26,21.5 \%)$ and divorce/divorcee employees $(n=2,1.7 \%)$. Employees with a degree qualification were 14 employees $(11.6 \%)$; this is followed by diploma holder employees $(n=41,33.9 \%)$ and certificate holders $(n=66,54.5 \%)$. In the length of service, forty-six employees $(38 \%)$ worked for more than 10 years. This is followed by employees who worked between 7 to 10 years $(n=25,20.7)$, employees who worked between 4 to 6 years $(n=25,20.7 \%)$, employees who worked 1 to 3 years $(n=19,15.7 \%)$, and employees who worked less than 1 year $(n=6,5 \%)$. The majority of the employees were having a working grade of 17 to $38(n=117,96.7 \%)$; this is followed by 3 employees $(2.5 \%)$ of grades 1 to 16 and one employees $(0.8 \%)$ of grade 41 to 54 .

Table 1. Demographic Analysis

\begin{tabular}{ccc}
\hline Items & $\mathrm{n}$ & $\%$ \\
\hline Gender: & & \\
Men & 92 & 24.0 \\
Women & 29 & 88.4 \\
\hline Ethnicity: & & 1.7 \\
Malay & 107 & 9.1 \\
Chinese & 2 & 11 \\
Ondian & 1 & 0.8 \\
\hline
\end{tabular}




\begin{tabular}{|c|c|c|}
\hline \multicolumn{3}{|l|}{ Age (years old): } \\
\hline Below 30 & 31 & 25.6 \\
\hline $30-40$ & 53 & 43.8 \\
\hline $41-50$ & 25 & 20.7 \\
\hline Above 50 & 12 & 9.9 \\
\hline \multicolumn{3}{|l|}{ Marital Status: } \\
\hline Married & 93 & 76.9 \\
\hline Single & 26 & 21.5 \\
\hline Others & 2 & 1.7 \\
\hline \multicolumn{3}{|l|}{ Education: } \\
\hline Certificate & 66 & 54.5 \\
\hline Diploma & 41 & 33.9 \\
\hline Degree & 14 & 11.6 \\
\hline \multicolumn{3}{|c|}{ Length of Service (years) } \\
\hline Below 1 & 6 & 5.0 \\
\hline $1-3$ & 19 & 15.7 \\
\hline $4-6$ & 25 & 20.7 \\
\hline $7-10$ & 25 & 20.7 \\
\hline Above 10 & 46 & 38.0 \\
\hline \multicolumn{3}{|l|}{ Work Grade: } \\
\hline Grade $41-54$ & 1 & 0.8 \\
\hline Grade $17-38$ & 117 & 96.7 \\
\hline Grades 1-16 & 3 & 2.5 \\
\hline
\end{tabular}

\subsection{Reliability Analysis}

Based on the reliability analysis, all variables were above the acceptable value of Cronbach's Alpha. Table 2 depicts the analysis, working conditions with 3 items $(\alpha=0.74)$, co-workers with 5 items $(\alpha=0.92)$, leadership styles $(\alpha=0.96)$, and job satisfaction $(\alpha=0.79)$.

Table 2. Reliability Analysis

\begin{tabular}{ccc}
\hline Variables & No. of Items & Cronbach's Alpha \\
\hline Working Conditions & 3 & 0.744 \\
Co-Workers & 5 & 0.915 \\
Leadership Styles & 4 & 0.959 \\
Job Satisfaction & 5 & 0.789 \\
\hline
\end{tabular}

\subsection{Correlations Analysis}

Table 3 depicts the correlations analysis among independent variables, namely working conditions, co-workers, and leadership styles toward the dependent variable that is job satisfaction. Employees indicated that their job satisfaction is highly correlated with working conditions $(\mathrm{r}=0.55)$ and leadership styles $(\mathrm{r}=0.54)$. Meanwhile, they indicated their job satisfaction is low with co-workers $(\mathrm{r}=0.27)$. 
Table 3. Correlations Analysis

\begin{tabular}{cccccc}
\hline & Variables & 1 & 2 & 3 & 4 \\
\hline 1 & Working Conditions & 1 & 0.168 & $0.535^{* *}$ & $0.554^{* *}$ \\
2 & Co-Workers & & 1 & $0.376^{* *}$ & $0.270^{* *}$ \\
3 & Leadership Styles & & & 1 & $0.541^{* *}$ \\
4 & Job Satisfaction & & & & 1 \\
\hline
\end{tabular}

** Correlation is significant at the 0.01 level (2-tailed).

\subsection{Regression Analysis}

Table 4 depicts the regression analysis, the employees indicated that their $\mathrm{R}^{2}$ was $40 \%$ on job satisfaction which was explained by working conditions $(\beta=0.38, p<0.00)$, co-workers $(\beta=0.09, p>0.10)$, and leadership styles $(\beta=0.31, p<0.05)$. The regression analysis indicated that $60 \%$ of the variance for job satisfaction was explained by other unknown additional variables that have not been explored. Furthermore, the regression model $(\mathrm{F}=25.81$, $\mathrm{p}<0.00$ ) was proven to be a significant model due to the $\mathrm{F}$ ratio being significant in predicting job performance. In conclusion, the working conditions and leadership styles were significant in predicting job satisfaction among employees in the local authority. Hypotheses $\mathrm{H}_{1}$ was supported in explaining the employees on their working conditions toward job satisfaction, and hypothesis $\mathrm{H}_{3}$ was supported in explaining the employees on their leadership toward job satisfaction. Unfortunately, the co-workers were not significant in predicting job satisfaction among employees in the local authority. Thus, hypothesis $\mathrm{H}_{2}$ was not supported in explaining the employees on their co-workers toward job satisfaction.

Table 4. Regression Analysis

\begin{tabular}{|c|c|c|}
\hline \multirow{2}{*}{ Variables } & \multicolumn{2}{|c|}{ Job Satisfaction } \\
\hline & $\beta$ & Sig. \\
\hline Working Conditions & 0.375 & 0.000 \\
\hline Co-Workers & 0.092 & 0.239 \\
\hline Leadership Styles & 0.306 & 0.001 \\
\hline $\mathrm{R}^{2}$ & \multicolumn{2}{|c|}{0.398} \\
\hline Adj. $R^{2}$ & \multicolumn{2}{|c|}{0.383} \\
\hline F-Change & \multicolumn{2}{|c|}{25.807} \\
\hline Sig. F-Change & \multicolumn{2}{|c|}{0.000} \\
\hline
\end{tabular}

\section{Discussions}

Based on the findings, this study has implications for the organization and top management is to take appropriate action in increasing job satisfaction. A mutually supportive, conducive, and attractive working environment can provide various benefits to the organization. This study suggests that leadership styles have an impact on the level of job satisfaction. According to literature highlights and studies conducted, the level of organizational management is influenced by charismatic leadership, skills, individual judgment, intellectual stimulation, good governance, and motivation that impact commitment and job satisfaction among employees for an organization. Employee commitment is influenced by the professionalism of individuals in performing their duties and responsibilities. Both of these elements determine the level of job satisfaction of the organization. Usually, job satisfaction and commitment to the organization can be achieved with an increase in self-achievement such as recognition, appreciation, and contribution.

Working conditions include aspects of equipment, workspace, work climate, adequate lighting, and so on. Overall, working conditions were satisfactory where the working conditions are considered good among employees. It provided comfort to employees to perform their duties well and satisfactorily. This situation contributed to job satisfaction as well as increasing productivity among employees. Koppes (2014) stated that job satisfaction can increase employee motivation with a conducive organization, structure, and organizational 
climate. Job satisfaction can be achieved with the management and employers who are concerned about the welfare of their employees. Thus, the top management can provide good facilities or utilities so that employees can achieve their maximum level of job satisfaction. Moreover, with conducive working conditions, the quality of work and thoughtful ideas can be contributed and in turn, can improve the reputation and achievement in their work. Besides, the workload received by employees was reasonable. It made respondents feel satisfied with their work. Yusoff, Kian, and Idris (2013) stated that there was a significant correlation between job satisfaction and working conditions. The satisfaction of working conditions can directly increase the employees' job satisfaction.

Good relationships among co-workers do not encourage employees to increase their job satisfaction. This is because each individual in the organization carries out their respective duties and does not depend on co-workers. Omar and Hamzah (2020) stated the organization is not influenced by co-workers who impact job satisfaction. Every teacher in an organization is not influenced by the relationships of co-workers. The findings of this study are contrary to the study conducted by Katz (2014) stated that good relationships, cohesion, harmony, and understanding with co-workers contribute to a high level of job satisfaction. Having good relationships among co-workers, indirectly the situation has a positive effect on job satisfaction. Good association with co-workers provides a high level of job satisfaction. Indirectly, good relationships among co-workers have an impact on job satisfaction.

Leadership styles greatly influence the success of an organization as well as job satisfaction among employees. The findings of this study can be attributed to the factor hygiene which involves aspects of supervision and leadership in managing the organization. It is adapted from a study conducted by Herzberg (1966) who placed leadership styles as a factor in hygiene determining employees to be satisfied or otherwise to their work. Moreover, Judge, Bono, Erez, and Locke (2016) stated that the relationship between employees and supervisors is part of the factors that drive towards job satisfaction. The attitude of a leader who adopts an open attitude and practices a harmonious relationship will be respected by the subordinates and will lead towards an increase in the level of job satisfaction. It is therefore clear that leadership styles have an impact on job satisfaction. It is supported by the findings of previous studies conducted by Emery and Barker (2007) where leadership styles are closely related to work performance and organizational success. When job performance is satisfactory, the success of the organization can be achieved in line with the work that can be proud of.

\section{Conclusion}

Overall, the construct of this study proves that there is a positive relationship in terms of significant variables and there is a strength between job satisfaction with work conditions, co-workers, and leadership styles. This situation shows that each aspect studied in detail in this study has an impact on the level of job satisfaction of employees. Therefore, every aspect and dimension needs to be carefully researched so that job satisfaction is always at the optimum level. In carrying out the responsibilities entrusted to them, employees also have their perceptions of the organization that influence job satisfaction. This perception has both positive and negative effects which can increase the level of motivation of employees and also shake their spirit in carrying out tasks. This situation should not be taken lightly because there is a correlation between employee perceptions of the organization to be able to influence job satisfaction. This situation needs to be addressed at least through the action or implementation of solutions in stages so that everything is under control. As can be seen, in carrying out the responsibilities entrusted to them, they are also burdened with many tasks, mental and physical preparation must be strong so that job satisfaction is achieved to determine the success of the organization. Besides, the leadership styles of the administration should be credible to set an example and be a role model to the public. Intrinsic factors such as a conducive environment, reasonable rewards, and balanced workplace politics are also factors that determine the success of an organization and influence work motivation among employees.

\section{Acknowledgement}

The authors would like to thank you to the Universiti Sains Malaysia for their grant support toward the publication of this article. Ref. No.1001/PJJAUH/8016077.

\section{References}

Al-Zu'bi, H. A. (2010). A study of relationship between organizational justice and job satisfaction. International Journal of Business and Management, 5(12), 102-109. https://doi.org/10.5539/ijbm.v5n12p102

Carlopio, J., \& Gardner, D. (1995). Perceptions of work and workplace: Mediators of the relationship between job level and employee reactions. Journal of Occupational and Organizational Psychology, 68(4), 321-326. https://doi.org/10.1111/j.2044-8325.1995.tb00590.x 
Chng, H. C., Hee, C. Y., Liew, P. M., \& Loke, L. B. (2014). Factors Affect Employees' Performance in Hotel Industry. Final Year Project, Universiti Tunku Abdul Rahman.

Deraman, S., \& Isa, S. Z. M. (2016). Tahap Kepuasan Kerja Dalam Kalangan Kakitangan Penjara. Jurnal Komunikasi Malaysian, 1, 149-161.

Emery, C. R., \& Barker, K. J. (2007). The effect of transactional and transformational leadership styles on the organizational commitment and job satisfaction of customer contact personnel. Journal of Organizational Culture, Communications and Conflict, 11, 77-90.

Fiedler, F. E. (1967). A Theory of Leadership Effectiveness. New York: McGraw-Hill.

Hamzah, M. R., Mahmuddin, A. A., Ayub, S. H., Ahmad, N., \& Nordin, N. (2010). Perbandingan Tahap Kepuasan Bekerja Dikalangan Staf Akademik dan Bukan Akademik: Kajian Kes Di Universiti Malaysia Perlis. ICoHSE Conference, 12-14 November 2010, Penang.

Herzberg, F. (1966). Work and the Nature of Man. Cleveland, OH: World Pub. Co.

Johari, H., \& Hee, O. C. (2013). Personality Traits and Customer-Oriented Behavior in the Health Tourism Hospitals in Malaysia. International Journal of Trade, Economics and Finance, 4(4), 213-216. https://doi.org/10.7763/IJTEF.2013.V4.288

Judge, T. A., Bono, J. E., Erez, A., \& Locke, E. A. (2016). Core self-evaluations and job and life satisfaction: The role of self-concordance and goal attainment. In G. J. Boyle, J. G. O'Gorman, \& G. J. Fogarty (Eds.), Sage Benchmarks in Psychology. Work and organisational psychology: Research methodology; Assessment and selection; Organisational change and development; Human resource and performance management; Emerging trends: Innovation/globalisation/technology (pp. 145-169). Sage Publications, Inc.

Jusoh, H., \& Ahmad, H. (2009). Keefisienan perkhidmatan pihak berkuasa tempatan di Wilayah Bandaraya Kuala Lumpur: Perspektif komuniti (The efficiency of local authorities in providing se rvices in the Kuala Lumpur city: A community perspective). Geografia Online, Malaysian Journal of Society and Space, 5(1), 54-68.

Karatepe, O. M. (2011). The Effects of Coworker and Perceived Organizational Support on Hotel Employee Outcomes: The Moderating Role of Job Embeddedness. Journal of Hospitality \& Tourism Research, 36(4), 495-516. https://doi.org/10.1177/1096348011413592

Katz, D. (1964). The Motivational Basis of Organizational Behavior. Behavioral Science, 9, 131-133. https://doi.org/10.1002/bs.3830090206

Katz, M. N. (2014). The International Relations of the Arab Spring. Middle East Policy, 21(2), 76-84. https://doi.org/10.1111/mepo.12072

Kee, H. P., Low, P. W., Ooi, C. K., Sam, M. K., \& Teng, C. H. (2012). A study on the impacts towards the loyalty of the employee among the back of house staffs in hotel industry. Final Year Project, Universiti Tunku Abdul Rahman.

Koppe, L. (2014). Historical Perspectives in Industrial and Organizational Psychology (3rd ed.). New York: Psychology Press. https://doi.org/10.4324/9781315820972

Lam, S. S. K. (1995). Quality Management and Job Satisfaction: An Empirical Study. International Journal of Quality \& Reliability Management, 12(4), 72-78. https://doi.org/10.1108/02656719510087337

Lee, S. Y., \& Brand, J. L. (2005). Effects of Control Over Office Workspace on Perceptions of the Work Environment and Work Outcomes. Journal of Environmental Psychology, 25(3), 323-333. https://doi.org/10.1016/j.jenvp.2005.08.001

Likert, R. (1967). The Human Organization: Its Management and Value. New York: McGraw-Hill.

Lin, S. C., \& Lin, J. S. J. (2011). Impacts of coworkers' relationships on organizational commitment and intervening effects of job satisfaction. African Journal of Business Management, 5(8), 3396-3409. https://doi.org/10.5897/AJBM10.1558

Locke, E. A. (1969). What is Job Satisfaction? Organizational Behavior and Human Performance, 4(4), 309-336. https://doi.org/10.1016/0030-5073(69)90013-0

Locke, E. A. (1976). The Nature and Causes of Job Satisfaction. In M. D. Dunnette (Ed.), Handbook of Industrial and Organizational Psychology (1297-1343). Chicago, IL: Rand McNally.

McNeely, R. L. (2008). Race and Job Satisfaction in Human Service Employment. Administration in Social 
Work, 13(1), 75-94. https://doi.org/10.1300/J147v13n01_06

Occhipinti, S. F., Rollo, N. M., \& Klimowicz, E. J. (2018). The Effects of Coworker Relationships, Involvement, and Supportiveness on Job Satisfaction and Performance. Student Publications, 610. Retrieved from https://cupola.gettysburg.edu/student_scholarship/610

Odom, R. Y., Boxx, W. R., \& Dunn, M. (1990). Organizational Cultures, Commitment, Satisfaction and Cohesion. Public Productivity and Management Review, 14, 157-169. https://doi.org/10.2307/3380963

Omar, N. S. H. C., \& Hamzah, M. I. M. (2020). Pengaruh Kepimpinan Distributif Guru Besar Terhadap Kepuasan Kerja Guru. International Journal of Education and Pedagogy, 2(2), 109-123.

Rad, A. M. M., \& Yarmohammadian, M. H. (2006). A study of relationship between managers' leadership style and employees' job satisfaction. Leadership in Health Services, 19(2), 11-28. https://doi.org/10.1108/13660750610665008

Raziq, A., \& Maulabakhsh, R. (2015). Impact of Working Environment on Job Satisfaction. Procedia Economics and Finance, 23, 717-725. https://doi.org/10.1016/S2212-5671(15)00524-9

Robins, R. W., Tracy, J. L., Trzesniewski, K., Potter, J., \& Gosling, S. D. (2001). Personality correlates of self-esteem. Journal of Research in Personality, 35, 463-482. https://doi.org/10.1006/jrpe.2001.2324

Rosliza, N. H. H., \& Bakar, N. R. A. (2018). Kepuasan Kerja dalam Kalangan Jururawat di Malaysia. Proceeding of the 5th International Conference on Management and Muamalah 2018 (ICoMM 2018).

Shaikh, M. A., Bhutto, N. A., \& Maitlo, Q. (2012). Facets of Job Satisfaction and Its Association with Performance. International Journal of Business and Social Science, 3(7), 322-326.

Simon, H. A. (1947). Administrative Behavior. New York: Free Press.

Spector, P. E. (1994). Using Self-Report Questionnaires in OB Research: A Comment on the Use of a Controversial Method. Journal of Organizational Behavior, 15, 385-392. https://doi.org/10.1002/job.4030150503

Tay, Y. N., Tan, C. H. Y., Lew, S., Tan, X. W., \& Chea, S. M. (2017). The Relationship between Work Environment and Job Satisfaction in Hotel Industry. Final Year Project, Universiti Tunku Abdul Rahman.

Vroom, V. H. (1964). Work and Motivation. NY: Wiley.

Wall, V. D. Jr., \& Nolan, L. L. (1986). Perceptions of Inequity, Satisfaction, and Conflict in Task-Oriented Groups. Human Relations, 39(11), 1033-1051. https://doi.org/10.1177/001872678603901106

Yusoff, W. F. W., Kian, T. S., \& Idris, M. T. M. (2013). Herzberg's Two Factors Theory on Work Motivation: Does Its Work for Todays Environment? Global Journal of Commerce \& Management Perspective, 2(5), 18-22.

\section{Copyrights}

Copyright for this article is retained by the author(s), with first publication rights granted to the journal.

This is an open-access article distributed under the terms and conditions of the Creative Commons Attribution license (http://creativecommons.org/licenses/by/4.0/). 